\title{
LOS MURALES DE LA NICARAGUA REVOLUCIONARIA, 1979-1992. DAVID KUNZLE. MANAGUA: INSTITUTO DE HISTORIA DE NICARAGUA Y CENTROAMÉRICA DE LA UNIVERSIDAD CENTROAMERICANA (IHNCA-UCA), 2017. 364 PÁGINAS
}

Fidel de Rooy

Recibido: 07/07/2017 Aceptado: 04/08/2017

Debieron transcurrir veintidós años para que, finalmente, se confabularan los esfuerzos y los recursos necesarios para producir la edición en castellano de The Murals of Revolutionary Nicaragua, 1979-1992, ${ }^{1}$ el conocido estudio de David Kunzle ${ }^{2}$ publicado por la University of California Press, en 1995. Producto de un extraordinario trabajo colectivo del programa editorial del Instituto de Historia de Nicaragua y Centroamérica de la Universidad Centroamericana (IHNCA-UCA) en Managua, y con traducción a cargo de Frances Kinloch y David Traumann, vio la luz en mayo del 2017 el libro Los murales de la Nicaragua revolucionaria, 1979-1992. Esta publicación recoge el estudio -enriquecido- que el Dr. Kunzle realizó sobre el muralismo nicaragüense entre 1981 y 1993, doce años en los cuales el autor se dedicó a registrar, catalogar y reflexionar en torno a más de trescientas obras de arte público monumental con las que la Nicaragua revolucionaria vistió las avenidas, calles, caminos, escuelas, parques, instituciones y demás espacios públicos tanto de sus ciudades como del interior del país.

\section{Lo conservado de la edición en inglés}

La estructura central del diseño original de The Murals of Revolutionary Nicaragua, 1979-1992 se mantiene en su totalidad en esta nueva edición traducida al castellano. A un prólogo de Miguel d'Escoto Brockman, ${ }^{3}$ en que el ex ministro de Relaciones Exteriores del gobierno sandinista se limita a saludar la publicación como un valioso gesto de la solidaridad internacional frente a la agresión político-militar estadounidense hacia la Revolución, le sigue un texto del reconocido artista nicaragüense Raúl Quintanilla, ex director de la Escuela Nacional de Artes Plásticas y del Museo de Arte Contemporáneo en Managua.

En un breve ensayo titulado "Un diálogo suspendido: la Revolución y las artes visuales en Nicaragua", Quintanilla ofrece su versión personal sobre el nacimiento, a raíz del triunfo sandinista de 1979, de un nuevo "lenguaje visual" que "entretejía el compromiso social con la experimentación visual" (17), el cual supuso además una contestación de la “tradición restrictiva que jerarquizaba las artes” (18) que, después 
y antes del proceso sandinista, tendió a valorar la pintura al óleo como el súmmum en la plástica nacional.

A una sucinta exposición de los eventos que truncaron el proceso revolucionario y culminaron con el triunfo electoral de la Unión Nacional Opositora (UNO) en 1990, Quintanilla añade su denuncia de la entronización por parte del nuevo gobierno de políticas neoliberales en materia económica y cultural, y su protesta por las deleznables prácticas de destrucción del acervo muralista impulsadas desde la nueva Alcaldía de Managua. El artista cierra con "una de cal y otra de arena" para el gremio artístico de entonces, pues aunque elogia la aparición de grupos culturales alternativos al interior de los cuales se han "evaluado con franqueza las políticas culturales de la Revolución, sus aciertos y errores" (19), también señala a un sector de las asociaciones de artistas a las que acusa de haberse dejado cooptar $\mathrm{y}$, por ello, "han terminado por legitimar el vandalismo y la censura del nuevo gobierno" (19).

El texto en donde Kunzle expone su análisis histórico del muralismo nicaragüense aparece bajo el título "Introducción", y sirve como lectura preliminar al "Catálogo" comentado que constituye la porción más amplia del libro. En su "Introducción", Kunzle primero hace un repaso a la historia de hostilidad por parte de Estados Unidos hacia Nicaragua, al señalar las particularidades de las intervenciones militares que la nación del norte protagonizó a lo largo del siglo XX, su apoyo a la dictadura somocista y, finalmente, la agresión contra la Revolución sandinista orquestada por el gobierno de Ronald Reagan; agresión frente a la cual Kunzle se empeña en desmentir -sin renunciar al tratamiento crítico de la realidad interna nicaragüense- una serie de acusaciones propagadas por Estados Unidos sobre el proceso revolucionario e instaladas como "verdades" por el establishment mediático norteamericano.

Una de las secciones más absorbentes del estudio de Kunzle es su crónica sobre la política y las acciones de destrucción de los murales impulsadas a raíz de la llegada de Violeta Barrios de Chamorro (UNO) a la Presidencia de la República y de Arnoldo Alemán a la Alcaldía de Managua, ambos destacados opositores al sandinismo. En ese recuento detallado - a través de referencias periodísticas- de los sucesos que acabaron con la obliteración de la enorme mayoría de los murales capitalinos, Kunzle recoge el núcleo vivo de una polémica donde se enfrentaron el campo político con el artístico y que, sin duda, constituyó la querella más destacada del mundo del arte en la primera parte de la década de 1990 en Nicaragua; una querella que no se saldó sin la división interna del propio gremio artístico.

Esta segunda sección de la "Introducción" finaliza con una breve reseña histórica sobre la llegada al país de los primeros pintores internacionalistas desde Panamá, y algunas reflexiones críticas en torno a la nueva "visión comercial" de la estética capitalina de mediados de los años noventa bajo la alcaldía de Alemán, en la que para Kunzle "ahora, el modelo es Miami, la verdadera capital cultural de Nicaragua" (50). 
Las dos secciones más sustantivas del estudio del autor son, por un lado, las dedicadas a las temáticas de los murales revolucionarios y, por otro, al estilo eclético de estos. Frente a la bastedad de la obra del muralismo nicaragüense, que condensa la "experiencia vivida, tanto real como idealizada, a menudo prosaica y literal, bastante despreocupada de abstracciones, teoría o 'estética'” (51), Kunzle propone su agrupación en seis grandes temáticas pictóricas: a. La insurrección, o "el drama de los combates" (51); b. Poder popular, o la representación de la toma del poder por gente común y corriente; c. Una sociedad mejor: los programas sociales sandinistas, o la traducción pictórica del contraste entre los problemas sociales bajo la dictadura y las soluciones encontradas por el sandinismo; d. Una economía que también produce felicidad, o la percepción muralista de un proceso productivo de tecnificación modesta "destinado a contribuir a la felicidad humana" (58) de los campesinos; e. Cultura es revolución, revolución es cultura, o la representación visual de la democratización de la cultura; y f. El panteón sandinista, o la eternización muralista de los mártires.

En la sección dedicada al eclecticismo estilístico de las obras, Kunzle encuentra tres vertientes presentes en el muralismo nicaragüense: a. El primitivismo, definido por un "imaginario paradisiaco y tranquilo que presenta pequeñas figuras humanas en medio de junglas pletóricas de color" (106); b. El modelo mexicano, de influencia obligada por el peso que el movimiento muralista de México tuvo en toda América Latina ${ }^{4}$ y recibido con problemas por los artistas nicaragüenses, pues "su presencia como modelo a seguir les parecía demasiado obvia" (108); y c. El modelo precolombino, dominado por la iconografía indígena que en Nicaragua se utilizó más bien para "plasmar motivos folclóricos... en vez de temas políticos" (109). Adicionalmente, Kunzle se dedica en su texto a contar la historia del surgimiento de la primera escuela de muralismo en Nicaragua y la producción de los primeros murales en las ciudades de Managua, Estelí y León; las contribuciones de los internacionalistas y el papel del financiamiento europeo; y un breve análisis de otras prácticas del arte público en la Nicaragua revolucionaria, como grafitis, vallas y afiches.

\section{Lo nuevo de la edición en castellano}

El más evidente y valioso aporte que esta nueva edición en castellano hace al trabajo de Kunzle se refleja en la extraordinaria y renovada calidad del soporte físico del libro. El equipo editorial del IHNCA-UCA no solo logró hacerse de una copia de los fotogramas originales completos del archivo de Kunzle, sino que además sometió las fotografías a un nuevo proceso de digitalización, recorte y corrección de color que anuncia, desde que se aprecia la portada, la calidad visual contenida al interior del catálogo.

Otro gran acierto fue la ampliación del tamaño de página y la disposición horizontal de la publicación, lo que hizo posible una composición mucho mejor aprovechada del texto y las imágenes del catálogo. La decisión de imprimir toda la obra en full 
color y de reencuadrar cada imagen, en tanto fuera posible, para preservar el contexto del espacio público en donde se desenvolvía cada mural, resulta en una experiencia visual novedosa y única para quien decide zambullirse en este pedazo de la memoria viva del pueblo nicaragüense.

Un epílogo de Sergio Michilini, pintor de origen italiano radicado en Nicaragua desde 1982 y figura central en el desarrollo del movimiento muralista nicaragüense, complementa la edición en castellano. Michilini, promotor y fundador de la Escuela Nacional de Arte Público-Monumental David Alfaro Siqueiros (ENAPUM-DAS), inaugurada en 1984, aborda en su texto un relato inédito y minucioso sobre su temprana experiencia con los muralistas de Nicaragua y los esfuerzos por consolidar el movimiento. Luego de relatar las gestiones y trabajos iniciales para hacerse de unas instalaciones adecuadas para la Escuela, Michilini expone las ideas que inspiraron el diseño programático de la ENAPUM-DAS cuya creación asumió un doble objetivo: por un lado, "implementar la investigación y experimentación de técnicas pictóricas y escultóricas" y, por otro, "formar a los nuevos pintores y escultores para trabajar en los planes de reconstrucción física de las ciudades destruidas" (345).

A partir del análisis de reconocidas experiencias históricas en formación artística -como la Bauhaus de Alemania, el Taller Gaudì de Barcelona y el Taller Siqueiros en México-, la oferta didáctica de la ENAPUM-DAS contempló asignaturas de pintura al fresco, mosaico de piedras, composición, poliangularidad, diseño y metodología del trabajo colectivo, entre otras. Michilini continúa ahondando en la experiencia muralista al relatar el trabajo de la Escuela en proyectos de gran envergadura por encargo de distintas entidades de Gobierno -como el caso de los murales producidos en la ciudad de San Carlos, al sur del país-, la génesis de El andamio -la revista de la ENAPUM-DAS- y, finalmente, el inicio de los enfrentamientos con la burocracia estatal que acabarían con la Escuela y luego con los murales, una vez que se produjo la derrota electoral sandinista en 1990.

Otra novedad de la edición a cargo del IHNCA-UCA es un listado catalográfico de murales sin imágenes, obras registradas en el archivo del autor y comentadas por él, pero sin soporte fotográfico. El "Catálogo" que ocupa la porción central del libro está organizado del siguiente modo: una primera sección se dedica a mostrar los murales de la capital, Managua, iniciando con los del centro de la ciudad para luego pasar a los barrios y suburbios; y una segunda parte recoge una exposición de las obras producidas en los diferentes departamentos del país, tanto en algunas de las ciudades principales, como en los espacios más rurales. Finalmente, el libro aporta breves reseñas biográficas tanto de los principales muralistas como de los fotógrafos involucrados en el levantamiento del archivo visual del catálogo.

Los murales de la Nicaragua revolucionaria, 1979-1992 se reafirma como un clásico de referencia obligatoria en el estudio del arte público y político nicaragüense. 
Kunzle y el IHNCA-UCA lograron, con esta nueva edición en castellano, resarcir una deuda de larga data con el público nicaragüense y centroamericano que, hasta ahora, no tenía acceso en su idioma a la obra más importante sobre el muralismo en Nicaragua y que, no hay duda, se ha convertido también en un monumento académico a la memoria de un pueblo que un día pintó en las paredes sus propias aspiraciones de transformación.

\section{Notas}

1 Kunzle, David. The Murals of Revolutionary Nicaragua, 1979-1992. Berkeley, Los Ángeles y Londres: University of California Press. 1995.

David Kunzle, originario de Birmingham, Inglaterra, se formó en Historia del Arte en las universidades de Cambridge y de Londres, en donde obtuvo su doctorado. Decidido activista contra la guerra en Vietnam en las décadas de 1960 y 1970, sus posturas políticas le costaron un despido arbitrario de la Universidad de California en Santa Bárbara, entidad a la que fue reintegrado en 1977 pero esta vez en la ciudad de Los Ángeles (UCLA). Desde entonces empezó a interesarse por el arte público y el arte político, y a día de hoy ha escrito alrededor de 135 artículos y 12 libros principalmente en el campo del arte popular, público y revolucionario. Retirado de su trabajo universitario con el rango de Distinguido Profesor Emérito desde 2010, Kunzle no ha cesado sus inquietudes intelectuales y mantiene en activo la publicación de los resultados de su actividad como historiador.

3 Miguel d'Escoto Brockman fue un célebre diplomático, político y cura católico nicaragüense de la corriente de la teología de la liberación, internacionalmente reconocido por su labor al frente del Ministerio de Relaciones Exteriores del gobierno sandinista a lo largo de la década de 1980. Se destacó por una astuta y férrea defensa de la Revolución sandinista en la escena internacional, frente a la agresión político-militar del gobierno estadounidense. Falleció en junio de 2017.

$4 \quad$ El primer taller de muralismo fundando en Nicaragua por Sergio Michilini, pintor de origen italiano, se denominó Escuela Nacional de Arte Público-Monumental David Alfaro Siqueiros (ENAPUM-DAS).

Fidel de Rooy, nicaragüense radicado en Costa Rica, es egresado de la Licenciatura en Sociología por la Universidad de Costa Rica (UCR). Se ha desempeñado en diversas labores editoriales para el Anuario de Estudios Centroamericanos y es colaborador desde 2010 del Portal de Sociología Latinoamericana, ambos proyectos del Instituto de Investigaciones Sociales (IIS) de la UCR. Estuvo vinculado, entre 2004 y 2006, al Instituto de Historia de Nicaragua y Centroamérica de la Universidad Centroamericana (IHNCA-UCA) de Managua, a través del proyecto El Tren Cultural. En la actualidad colabora en el desarrollo de dos investigaciones sobre arte y política en Nicaragua.

Contacto: fderooy@gmail.com

ORCID: 0000-0002-7116-1835 
